\title{
Sustainable development and groundwater resources exploitation
}

\author{
F. Villarroya · C. R. Aldwell
}

F. Villarroya

Senior Lecturer. Departamento de Geodinámica. Facultad de Ciencias Geológicas. Complutense University. E-28040 Madrid, Spain
C. R. Aldwell

Geological Survey of Ireland, Beggars Bush, Haddington Road, Dublin 4, Ireland

\begin{abstract}
In evaluating groundwater development both the positive and negative effects must be con-sidered; otherwise biased conclusions may be reached. Only with equal concern for the needs of present and future generations, fair exchange of technology between countries and user involvement can sustainable groundwater development be achieved. Examination of the use of the term aqui-fer overexploitation shows that there is no agree-ment on a single definition. In most cases it relates to the overuse of aquifers, but in other cases it is a planned overuse. In Spain, overexploitation is dealt with in the water act and implemented by the regu-lations that enforce that act. Experience has shown that without the cooperation of the water users themselves, good results are not obtained. Relevant education is urgently needed for the public and those decision makers responsible for determining the correct use of groundwater resources for the present and future generations.
\end{abstract}

Key words Groundwater development · Aquifer overexploitation

\section{Introduction}

The 1990s have so far been characterized by much concern for the environment. An important aspect of the environment is the concept of sustainable development -the use of natural resources in a way that will not destroy those needed by future generations. Among the conferences that have dealt with sustainable development in recent years are the following: UNDP Symposium on "A strategy for water resources capacity building", held in 1991 in Delft (The Netherlands); 23rd Congress of IAH on aquifer overexploitation held in the Canary Islands in 1991; International Conference on "An agenda of science for environment and development into the 21st century" (ASCEND 21), held in Vienna in 1991; the International Conference on water and the environment, held in Dub-lin in 1992; the United Nations Conference on environ-ment and development (UNCED), held in Rio de Janeiro in June 1992; the 2nd International Conference on envi-ronmental pollution held in Sitges (Spain) in 1993 and the Conference on future groundwater resources at risk, held in Helsinki in 1994. There have also been confer-ences about sustainable use of groundwater in the USA's western states.

During the last five years there has been considerable debate and discussion over the use of the term overexploitation of aquifers, especially in Spain. Some important studies on this subject have been published by the International Association of Hydrogeologists-Spanish Chapter (AIH-GE). The AIH-GE organized two scientific meetings on this subject, in 1989 and 1991. In both congresses the problem of aquifer overexploitation was discussed. The second took place at the 23rd Congress of the IAH. The presentations given make an important contribution to the subject (Pulido-Bosch and others 1989; Candela and others 1991).
A workshop on this subject was convened in 1991 by UN-DTCD (Dijon and Custodio 1992) and took place in Spain. The IAH has published a selection of the papers presented at the 23rd Congress of IAH (Sim-mers and others 1993) which is the latest book published on the topic.

\section{Are future groundwater resources at risk?}

To answer the question whether future groundwater re-sources are at risk, it is necessary to study both the quantity and quality aspects of groundwater. Water (sur-face and groundwater) is one of the most pervasive sub-stances on Earth. The total volume of all water is about 1400 million $\mathrm{km}^{3}$, but only $2 \%$ is freshwater. The current rate of withdrawal is about $3500 \mathrm{~km}^{3} /$ year, some 2100 $\mathrm{km}^{3}$ for consumptive use, while $1400 \mathrm{~km}^{3}$ of wastewater

The concept of overexploitation and sus-tainable groundwater development are defined and discussed in this paper. 
is returned to rivers. Groundwater withdrawals (percent by sectors) are: domestic (8), industry (23) and agriculture (69) (Shiklomanov 1991). Margat (1991) stressed the need to improve water evaluation studies and quantified the amount of groundwater pumpage use in various countries. His list places the first fifteen countries as follows (in $\mathrm{km}^{3}$ per year): India 150, USA 101, China 74.6, USSR (former) 45, Pakistan 45, Iran 29, Mexico 23, Japan 13.1, Italy 12.1, Germany 9.5, Saudi Arabia 7.4, France 7, Spain 6.3, Turkey 5 and Madagascar 4.9.

The main threat to groundwater today is from point and diffuse source pollution. Therefore groundwater quality protection is the key issue of groundwater resources policy in the industrialized countries. There are many sources of risk to groundwater, as discussed in the seminar on groundwater for the EU countries. RIVM and RIZA (1991) summarize the problems and threats to groundwater resources (Table 1). The current practices in all the EU countries lead to a non-sustainable use of groundwater systems. The dramatic Dublin Statement emphasizes the unsustainable use of groundwater: "Human health and welfare, food security, industrial development and the ecosystems on which they depend, are all at risk, unless water and land resources are managed more effectively in the present decade and beyond than they have been in the past" (UNESCO-WMO 1992).

\section{Groundwater resources exploitation and sustainable development}

What does sustainable development mean?

According to Fyfe (1993), sustainable development means: "will I leave this planet in a better condition for all species which follow me than when I arrived?" or, "do my actions restrict the opportunities for all those who follow?". In fact, we are asking if we are using wisely the resources needed for our life-support system.

The general conclusion of the seminar of ministers of the Environment of the EU countries (RIVM and RIZA 1991), was that in many countries sustainable use of groundwater for drinking and other (industrial, ecological, etc.) functions is being threatened, especially in the agricultural and industrial core regions of the EU.

Sustainable development must satisfy present needs without jeopardizing the ability of future generations to satisfy theirs. Overexploitation may take place during a period to allow better use of other resources, or while other technologies develop. Uncontrolled aquifer development easily leads to extensive aquifer exploitation and even to severe forms of overexploitation (Custodio 1993).

Aquifer exploitation and sustainable development Margat (1993) speaks of Malthusian underexploitation in the case of inadequate use of an aquifer. In the opinion of Custodio (1993), "intensive aquifer exploitation is a source of wealth, which fosters regional development and helps to guarantee a supply until other water sources can be economically developed".

Groundwater overexploitation has a series of negative consequences, such as increasing water cost, environmental changes (affects on wetlands, salinity problems, etc), reduction of other water sources already in use, water salinization and impairment of quality. The net result, however, may be either negative or positive. Positive results dominate at a regional level, but negative results are "news that trigger alarm bells and Malthusian forecasts under the heading of overexploitation" (Custodio 1993). On the other hand, intensive exploitation or overdraft are mainly points of view, referring to the consequences of intensive groundwater use, as perceived by environmen-

Table 1

Main problems and threats to sustainable use of groundwater in EU countries (based on R.I.V.M. and R.I.Z.A. 1991)

\begin{tabular}{|c|c|c|}
\hline Urban and industrial threats & Agricultural threats & Other threats \\
\hline $\begin{array}{l}\text { Landfills } \\
\text { Surface impoundments } \\
\text { Injection and underground } \\
\text { storage } \\
\text { Hazardous waste sites } \\
\text { Dredged sediments } \\
\text { Mining waste } \\
\text { Fuel storage tanks } \\
\text { Line sources }\end{array}$ & $\begin{array}{l}\text { Nitrate: use of manure } \\
\text { use of fertilizers } \\
\text { total nitrogen load } \\
\text { sensitivity of soils to nitrate leaching } \\
\text { estimation of the actual nitrate leaching } \\
\text { actual pollution based on monitoring data } \\
\text { Potassium } \\
\text { Pesticides: their use } \\
\text { atmospheric deposition } \\
\text { sensitivity of soils to leaching of pesticides } \\
\text { computed pesticide leaching, } \\
\text { monitoring data } \\
\text { ecological threats }\end{array}$ & $\begin{array}{l}\text { (Heavy) metals } \\
\text { Acidification and the risks of aluminium } \\
\text { leaching } \\
\text { Lowering of groundwater levels by } \\
\text { overexploitation } \\
\text { Lowering of groundwater levels by regulation } \\
\text { of surface waters } \\
\text { Lowering of groundwater levels by intensified } \\
\text { drainage } \\
\text { Lowering of groundwater levels by changes in } \\
\text { land use } \\
\text { Raising of groundwater levels by stopping } \\
\text { abstractions and artificial recharge } \\
\text { Economic consequences } \\
\text { Ecological consequences } \\
\text { Threats to sustainability of groundwater use: } \\
\text { threats to functionality of groundwater } \\
\text { threats to the diversity of ecosystems }\end{array}$ \\
\hline
\end{tabular}


talists, the news media and the public in general, and place emphasis on the adverse or detrimental aspects. Therefore, in order to evaluate groundwater exploitation, not only negative effects but also positive ones have to be considered: "otherwise a biased appraisal may be reached. Normally, practice shows us that beneficial aspects dominate over detrimental ones in most practical situations" (Custodio 1993). According to this last author, the most serious cause of aquifer exploitation is ignorance of what is happening, and negligence in producing the data needed to evaluate the hydrogeological and economic situation correctly. Another harmful effect is the irresponsible overreaction of water authorities, especially when they are poorly informed or lack the scientific and technical skills to evaluate current problems correctly. The most important action is to solve problems as they appear and not waste time and energy in defining terms. Any exploitation of water resources that is not managed in an integrated way, taking into account the needs of the present and future generations, puts these resources at risk. Such development therefore is not sustainable.

\section{Regulatory issues related to aquifer overexploitation}

\section{Aquifer overexploitation}

The introduction lists several recent conferences which have highlighted overexploitation of aquifers. Within the conference proceedings, there is no single agreed definition of overexploitation. Spanish Legislation (Royal Decree 849/1986) defines it in article 171.2 in the following terms: "An aquifer shall be considered to be overexploited, or in danger thereof, if the reserves existing therein are being placed in immediate danger as a result of annual withdrawals that are in excess of, or very close to, the volume of the average annual recharge (renewable resource) or which give rise to serious deterioration in the quality of the water".

According to Dijon and Custodio (1992), exceeding the limits of a renewable resource is not necessarily overexploitation. Conversely, staying within the limits of the same does not necessarily imply that all undesirable effects are being avoided and the beneficial effects enhanced.

Llamas (1992) suggests either the elimination or a very restricted use of the term. In brief, he defines overexploitation "sensu stricto" as all extraction of groundwater which has effects (physical, chemical, economic, ecological or social) which are negative for human life, now or in the future. This type of overexploitation should be avoided for moral reasons. For exploitation based on the extraction of water greater than the average recharge of the aquifer he suggests the term "overexploitation sensu lato".

In the papers presented at the 23rd International Congress of IAH, it was stated that in many cases, overex- ploitation is synonymous with inefficient exploitation of an aquifer (Villarroya 1994; Villarroya and Rebollo 1993). During this congress numerous examples of "excessive exploitation" (Custodio 1991) from all over the world were presented, and a summary can be found in Dijon and Custodio (1992).

\section{Overexploited aquifers, land-use planning and regulatory compliance}

In Spain, groundwater has been public property since the 1985 Water Legislation. For this reason any well which has a yield of more than $7000 \mathrm{~m}^{3} /$ year must have an official licence. The water authority of the river basin can declare there is overexploitation of an aquifer and order a limit to the withdrawals of water to achieve a more rational exploitation. Areas where no new exploitation may take place may be established.

What steps can be taken when an aquifer is declared overexploited? Under the 1985 Water Act the following procedures take, place (Art. 171, 172 and 173):

1. Provisional declaration of overexploitation and delimitation of the affected area.

2. Cessation of new concessions for the abstractions of groundwater including wells with less than $7000 \mathrm{~m}^{3} /$ year.

3. The compulsory formation of a water users' association if it does not already exist.

4. The water authority works out a methodical Plan of Abstractions after consulting the water users' association, makes it public and submits it for consideration to the board of the water authority.

5. Finally, the river basin executive committee approves the plan in the event that the aquifer has been found to be definitely overexploited.

6. The plan of abstractions for the river basin will be modified to take into account the declaration of overexploitation.

7. Meters may be installed to control the abstraction.

8. To enforce the measures ordered under the plan, a development committee will be formed and will report annually.

9. The water authority can authorize restrictions for new groundwater concessions and order the formation of a water users' association.

In this way there is a control of activities or uses which can affect the quality or quantity of the groundwater and which should receive the support of the water board. These activities include mining, urbanization, agriculture, cattle farming, industry and recreation.

\section{How can a lack of water resources affect land-use planning?}

As already described, the overexploitation of an aquifer has a marked influence on the planning and uses of land. Water users' associations will play a very important role in regulating the exploitation of natural resources in general, and especially of water resources. The participation of citizens through NGOs such as the water users' associations has been shown to be very effective and, on 
many occasions, has alleviated serious problems concerning the exploitation of the water resources of a region.

The associations have also been shown to be effective as watchdogs to ensure that restrictions and regulations are being complied with. In this sense water authorities should treat them as allies and not opponents. In some situations groundwater has an strategic role at an international level. Some authors emphasize the important role groundwater can play in securing at least a temporally independent supply. Good examples of this type of supply are found in the near-eastern countries. Margat (1992), distinguished three types of situation:

1. Countries with renewable resources (therefore independent of others): Lebanon, Yemen, The Cisjordan and Magreb states.

2. Countries without renewable resources which mine water; the Arab Emirates, Qatar, Oman, Syria and Saudi Arabia. Sooner or later, they will become dependent on other states.

3. Countries which depend heavily on others for water; Egypt, Sudan, Syria, Iraq, Israel and Jordan.

Margat foresees a future of "exchanging water for oil" between these near-eastern countries, and the establishment of new relations forced by lack of water. Shamir (1993) goes even further and considers water to be an extremely important factor in peace negotiations. Thus, water is not only a valuable resource but can also be an instrument in leading to peace (or war?) between neighbouring countries.

\section{Involvement and education}

Postel (1993) in "The last oasis" writes about efficiency and equity for the good management of water. Participation and education also seem to be the keys for the future of water management. Many scientific meetings of recent years have emphasized these aspects of management (Congresses of Dublin, Delft, Vienna, etc.; see also Fyfe 1993; Llamas and others 1992; Llamas 1996).

A water policy which only considers the needs of the present generation, and lacks a moral sense, is wrong. Among the problems which engage us today are water problems and others associated with the growing deterioration of the environment, often considered as an insignificant tip of the iceberg.

These problems are derived from a deep ethical crisis in human values. Llamas (1996) provides three basic principles for the new water management: "solidarity, subsidiarity and involvement". Certainly "solidarity" must be established between the present generation and future ones. For this reason moderation in the use of resources must become our normal behaviour. "Subsidiarity" is the transfer of essential technology between countries without seeking excessive profit. Lastly, the critical participation of the public should motivate those responsible for water management and encourage them to even greater efforts.
Water users' associations, which are envisaged in water acts like the Spanish one, should not only be considered as legal instruments but also be used as efficient tools for the good management of aquifers. Also scientific and professional associations, like the International Association of Hydrogeologists (IAH) must endeavour to increase their influence in society and in those agencies where decisions over water are taken. The authors hope that professional associations such as the IAH will accept and fulfill this new challenge.

\section{Conclusions}

In the short term, groundwater quality problems will be more serious than those of quantity. Between now and the end of the century the implementation of measures to prevent pollution of groundwater from diffuse and point sources will be the main issue.

Besides the networks for quantity or quality control, a water users' association can be effective in solving and watching over the correct working of proposed development plans.

The definition of aquifer overexploitation is unclear and controversial. In the majority of cases it refers to the incorrect use of an aquifer, in others it is planned.

To evaluate groundwater exploitation not only positive effects have to be considered, but also negatives ones; otherwise a biased appraisal may be reached.

Spanish legislation lays down the steps to be taken once an aquifer is declared overexploited, giving special importance to the compulsory formation of a water users' association and the preparation of a working plan for abstractions. At the same time the water authorities can delineate protection zones with restrictions on the use of an aquifer. The application of this approach is controversial and can be of great political importance.

Only with solidarity, subsidiarity and involvement can sustained groundwater development be achieved. Their practical application demands a parallel effort in education and information for the general public. Scientific associations like the IAH and the NGOs should be involved in this process.

\section{References}

Candela L, Gómez MB, Puga L, Rebollo LF, Villarroya F(eds) (1991) Aquifer overexploitation. Proc XXIII Int Congr (Spanish Chapter). IAH, Madrid

Custodio E (1991) Characterisation of aquifer overexploitation: comments on hydrogeological and hydrochemical aspects: the situation in Spain. In: Candela and others (eds) Aquifer overexploitation. Proc XXIII Int Congr, vol 1, IAH, Madrid, pp 3 19 
Custodio E (1993) Aquifer intensive exploitation and overexploitation with respect to sustainable development. In: Nath and others (eds) Proc Environ Poll ICEP 2. European Centre for Pollution Research, vol. 2, pp 509-516

Dijon R, Custodio E (eds) (1992) Groundwater overexploitation in developing countries. Report of an Interregional Workshop. Las Palmas, Canary Islands, Spain. United Nations, Department of Technical Cooperation for Development, New York

FyfE WS (1993) Sustainable resources for ten billion. Is it possible? In: Proc Geología Ambiental y Ordenación del Territorio, vol. 1. Sociedad Española de Geología Ambiental y Ordenación del Territorio. Madrid, pp 27-32

Llamas MR (1992) La surexploitation des aquifères: aspects techniques et institutionnels. Hydrogéologie 4:139-144

Llamas MR (1996) Future urban water problems and possible solutions. Preprint in: L'eau et la vie des hommes du XXIème siecle. Unesco, Paris

Llamas MR, BaCK W, Margat JT (1992) Groundwater use: equilibrium between social and potential environmental costs. Appl Hydrogeol 1, 2:3-14

Margat J (1991) Les eaux souterraines dans le monde. Similitudes et différences. Proc 21 Journées de Hydraulique. Sophia Antipolis, France, IV, pp 1-13

MARGAT J (1992) La lucha por el agua (The fight for water). Newspaper "El País" 11 June 92, pp 40-41

Margat J (1993) The overexploitation of aquifers. In: Simmers and others (eds) Selected papers of IAH vol. 3. IAH, Hannover, pp 29-40

Nath B, Candela L, Hens L, Robinson JP (eds) (1993) Environmental Pollution. European Centre for Pollution Research. Two vols. London

Postel S (1993) Last oasis: facing water scarcity . World Watch Institute, Washington DC
Pulido-Bosch A, Castillo A, Padilla A (1989) La sobreexplotación de acuíferos. Proc Congr Nat Aquifer Overexploitation. IAH, Madrid

RIVM and RIZA (eds) (1991) Sustainable use of goundwater. Problems and threats in the European communities. Report $\mathrm{n}^{\circ}$ 600025001, The Hague

Royal Decree (1986) Reglamento del Dominio Público Hidráulico Real Decreto 849/1986. Bol Ofic Estado 30 April 1986

Shamir U (1993) Development and management of groundwater resources: general principles and the case of Israel. Las Aguas Subterráneas. Importancia y perspectivas. Instituto Tecnológico GeoMinero de España, Real Academia de Ciencias, Madrid, pp 135-147

SHIKLOMANOV IA (1991) The world water resources: how much do we really know about them? 25 year commemorative symposium UNESCO, IHD/IHP Paris, pp 93-126

Simmers I, Villarroya F, Rebollo LF (eds) (1993) Aquifer overexploitation. Selected papers of IAH vol 3. IAH, Hannover

UNESCO-WMO (1992) The Dublin Statement. UN International Conference on Water and the environment (ICWE) UNESCO, Paris

Villarroya F (1994) Regulatory issues mainly about aquifer overexploitation within the scope of sustainable development. IAHS. Publication $\mathrm{N}^{\circ} 222$

Villarroya F, Rebollo LF (1993) Sobreexplotación de acuíferos: su significado y alcance (Aquifer overexploitation: concept and scope). Proc Reunión de Geología Ambiental y Ordenación del Territorio. Sociedad Española de Geología Ambiental y Ordenación del Territorio, vol. 1, Madrid, pp 201204 